\title{
Simpanan Anggota, Pinjaman Anggota, dan Jumlah Anggota dan Pengaruhnya terhadap Sisa Hasil Usaha (Studi: Koperasi Simpan Pinjam Wanita "Teratai" Periode 2016-2020)
}

\author{
*Yustika Pretty Andaresta, Juliani Pudjowati, Nurul Imamah \\ Fakultas Ekonomi dan Bisnis Universitas Bhayangkara Surabaya, Indonesia
}

DOI: 10.46821/bharanomics.v2i1.191

\begin{abstract}
Abstrak
Penelitian ini bertujuan untuk mengetahui dari simpanan anggota, pinjam ananggota dan jumlah anggota yang berpengaruh sedara dominan terhadap SHU Di Koperasi Wanita 'Teratai" tahun 2016-2020. Pengambilan data di lakukan di kantor Balaidesa Sidorejo menggunakan data Sekunder, yaitu data Pertumbuhan simpanan anggota, Pinjaman Anggota, Jumlah Anggota dan Sisa Hasil Usaha tahun 2016-2020. Metode analisi yang digunakan dalam penelitian ini adalah menggunakan analisis regresi linear berganda. Teknik pengujian data yang digunakan meliputi uji normalitas, uji multikolinearitas, uji heteroskedastisitas dan analisis regresi linear berganda. Hasil analisis regresi berganda memperoleh persamaan $Y=$ $19590,216+6,368 X 1+1,781 X 2+512,067 X 3$ dengan perhitungan: a) nilai signifikan sebesar 0,791 lebih besar dari tingkat kekelituan a=0,05 maka dapat diambil kesimpulan untuk menolak hipotesis artinya simpanan tidak berpengaruh terhadap sisa hasil usaha. b) nilai signifikansi sebesar 0,015 lebih kecil dari tingkat kekeliruan $\alpha=0,05$ maka dapat diambil kesimpulan untuk menerima hipotesis. Artinya pinjaman anggota berpengaruh terhadap sisa hasil usaha pada Koperasi Wanita "Teratai". c) nilai signifikan sebesar 0,967 lebih besar dari tingkat kekeliruan a=0,05 maka dapat diambil kesimpulan untuk menolak hipotesis artinya jumlah anggota tidak berpengaruh terhadap sisa hasil usaha.
\end{abstract}

Kata Kunci: Jumlah Anggota, Pinjaman Anggota, Simpanan Anggota, Sisa Hasil Usaha.

\begin{abstract}
:
This study aims to determine from member savings, member loans and the number of members who have a dominant influence on SHU in the "Teratai" Women's Cooperative in 2016-2020. Data collection was carried out at the Sidorejo Balaidesa office using secondary data, namely data on the growth of member savings, member loans, number of members and remaining operating results for 2016-2020. The analytical method used in this research is using multiple linear regression analysis. Data testing techniques used include normality test, multicollinearity test, heteroscedasticity test and multiple linear regression analysis. The results of multiple regression analysis obtained the equation $Y=19590,216+6,368 X 1+$ $1,781 X 2+512,067 X 3$ with the calculation: a) a significant value of 0.791 is greater than the kekelituan level $a=0.05$, so it can be concluded to reject the hypothesis that savings have no effect to the remaining operating results. $b$ ) the significance value of 0.015 is smaller than the error rate $=0.05$, so it can be concluded to accept the hypothesis. This means that member loans have an effect on the remaining operating results of the "Teratai" Women's Cooperative. c) a significant value of 0.967 is greater than the error rate $a=0.05$, so it can be concluded to reject the hypothesis, meaning that the number of members has no effect on the remaining operating results.
\end{abstract}

Keywords: Number of Members, Member Loans, Member Savings, Remaining Operating Results. 


\section{PENDAHULUAN}

Koperasi adalah salah satu bentuk usaha berbadan hukum yang berdiri di Indonesia. Menurut Undang-Undang No 25 Tahun 1992 pasal 1 ayat 1 tentang perkoperasian, koperasi Indonesia adalah badan usaha yang beranggotakan orangorang atau badan hukum koperasi dengan melandaskan kegiatannya berdasarkan prinsip koperasi, sekaligus sebagai gerakan ekonomi rakyat yang berdasarkan asas kekeluargaan. Koperasi berperan positif dalam pelaksanaan pembangunan nasional di Indonesia, baik secara langsung maupun tidak langsung. Perkembangan dan pertumbuhan koperasi selama ini belum sepenuhnya menampakkan wujud dan peranannya.

Berdasarkan Keputusan Menteri Negara Koperasi dan Usaha Kecil dan Menengah Republik Indonesia No.96/KKEP/M.KUKM/IX/2004 pasal (1) koperasi simpan pinjam adalah koperasi yang kegiatannya meliputi usaha simpan pinjam yang dilakukan untuk menghimpun dana dan menyalurkannya melalui kegiatan koperasi simpan pinjam. Kegitatan itu adalah usaha simpan pinjam dari dan untuk anggota serta calon anggota.

Simpanan pokok dijelaskan dalam Pasal 33 ayat (1) dan ayat (2) bahwa simpanan pokok merupakan modal sendiri yang dibayarkan setiap anggota saat mendaftar menjadi anggota aktif koperasi.

Simpanan wajib Dalam Pasal 33 ayat (2) dijelaskan bahwa simpanan wajib dapat diambil kembali dengan cara yang sudah ditetapkan lebih lanjut di dalam AD/ART dan keputusan- keputusan rapat anggota dengan mengutamakan kepentingan koperasi. Simpanan wajib bukan merupakan modal permanen karena dapat diambil setelah jangka waktu yang telah ditentukan. Adapun perhitungan bunga simpanan sesuai dengan Keputusan Menteri Negara Koperasi dan Usaha Kecil dan Menengah Republik Indonesia No.96/KKEP/M.KUKM/IX/2004 pasal (16) dilakukan berdasarkan: a. Perhitungan secara umum didasarkan pada nilai nominal dikalikan dengan tingkat bunga perbulan. b. Apabila bunga simpaan dibayar dimuka didasarkan perhitungan antara jumlah nilai nominal dikalikan dengan tingkat bunga perbulan dikalikan dengan jangka waktu.

Pinjaman anggota Menurut Peraturan Menteri Koperasi dan Usaha Kecil dan Menengah Republik Indonesia No.20/PEM/M.KUKM/XI/2008 ayat (7) pinjaman adalah penyediaan uang atau tagihan yang dapat diberikan oleh koperasi kepada peminjam dan mewajibkan melunasinya setelah jangka waktu tertentu disertai dengan sejumlah imbalan dengan cara mengangsur. Adapun perhitungan besarnya bunga pinjaman sesuai dengan Keputusan Menteri Negara Koperasi dan Usaha Kecil dan Menengah Republik Indonesia No.96/KKEP/M.KUKM/IX/2004 pasal (22) adalah sebagai berikut: a. Cost plus pricing didasarkan pada perhitungan antara biaya koperasi simpan pinjam ditambahkan hasil usaha yang diinginkan. b. Marginal pricing didasarkan pada perhitungan antara biaya variabel ditambah dengan margin. c. Menetapkan suku bunga tertentu untuk membatasi anggota d. Menetapkan suku bunga murah untuk mendapatkan banyak anggota. Selain itu juga dapat dihitung besaran angsuran bunga pinjaman dengan cara: a. Sistem flat (tetap), perhitungan yang didasarkan pada perkalian tingkat bunga perbulan dengan saldo awal pokok pinjaman. b. Bunga menurun, perhitungan yang didasarkan pada perkalian antara tingkat bunga perbulan dengan sisa pokok pinjaman. 
Anggota koperasi adalah pemilik sekaligus pengguna jasa koperasi. Partisipasi anggota merupakan unsur utama dalam memacu kegiatan dan untuk mempertahankan ikatan pemersatu di dalam koperasi. Koperasi sebagai business entity dan sosial entity dibentuk oleh anggota-anggota untuk menggapai manfaattertentu melalui partisipasi. Partisipasi adalah kesediaan untuk membantu berhasilnya setiap program sesuai dengan kemampuan, setiap orang tanpa berarti mengorbankan kepentingan diri sendiri.

Tujuan koperasi dapat dilihat dalam Bab II pasal 3 UU No. 25 tahun 1992 yang berbunyi "Koperasi Indonesia bertujuan memajukan kesejahteraan anggota pada khususnya dan masyarakat pada umumnya serta ikut membangun tatanan perekonomian nasional dalam rangka mewujudkan masyarakat yang maju, adil, dan makmur berlandaskan Pancasila, Undang-Undang Dasar 1945". Dan dapat disimpulkan bahwa tujuan Koperasi Indonesia dalam garis besarnya meliputi tiga hal sebagai berikut: 1. Untuk memajukan kesejahteraan anggotanya. 2. Untuk memajukan kesejahteraan masyarakat. 3. Turut serta membangun tatanan perekonomian nasional. Banyak koperasi yang mempunyai anggota banyak akan tetapi usahanya tetap lesu dan kebanyakan mengalami kebangkrutan. Hal ini terjadi karena berbagai kendala: 1) masalah yang muncul dari segi jumlah anggota. Pertumbuhan jumlah anggota dalam koperasi berjalan lambat. Hal ini disebabkan kurangnya partisipasi anggota terhadap informasi dalam koperasi, sehingga koperasi masih sangat kesulitan untuk berkembang. Demikian pula untuk koperasi, koperasi akan berfungsi dengan baik dan berhasil jika mengikut sertakan partisipasi anggota, tanpa adanya partisipasi anggota mustahil koperasi dapat berhasil dengan baik. 2) Masalah yang muncul dari segi simpanan. Terbatasnya modal dalam koperasi menyebabkan sulitnya mengembangkan unitunit usaha yang tujuannya untuk meningkatkan kesejahteraan anggotanya. Berdasarkan latar belakang yang telah diuraikan diatas maka dapat dirumuskan masalah sebagai berikut : Apakah simpanan anggota berpengaruh secara signifikan terhadap sisa hasil usaha (SHU) pada Koperasi Wanita "Teratai"?, Apakah variabel pinjaman anggota berpengaruh secara signifikan terhadap sisa hasil usaha (SHU) pada Koperasi Wanita "Teratai"?, Apakah variabel jumlah anggota berpengaruh secara signifikan terhadap sisa hasil usaha (SHU) pada Koperasi Wanita "Teratai"?, Manakah dari variabel simpanan anggota, pinjaman anggota dan jumlah anggota yang berpengaruh secara dominan terhadap sisa hasil usaha (SHU)?

\section{TINJAUAN PUSTAKA}

\section{Pengertian Simpanan Anggota}

Simpanan anggota merupakan bentuk dari partisipasi anggota koperasi, berikut menurut para ahli mengemukakan terkait simpanan anggota. Menurut UU No. 25 tahun 1992 pasal 41 Simpanan Anggota dibagi menjadi dua yaitu:

a. Simpanan Pokok

Simpanan Pokok adalah sejumlah uang yang sama banyaknya yang wajib dibayarkan oleh anggota kepada koperasi pada saat masuk menjadi anggota. simpanan pokok tidak dapat diambil kembali selama yang bersangkutan masih menjadi anggota. 
b. Simpanan Wajib

Simpanan Wajib adalah jumlah simpanan tertentu yang tidak harus sama yang wajib dibayar oleh anggota kepada Koperasi dalam waktu dan kesempatan tertentu. Simpanan wajib tidak dapat diambil kembali selama yang bersangkutan masih menjadi anggota.

c. Simpanan Wajib

Simpanan wajib adalah jumlah simpanan tertentu yang harus dibayarkan oleh anggota dalam waktu dan kesempatan tertentu, seperti sebulan sekali. Jenis simpanan wajib ini dapat diambil kembali dengan cara yang diatur lebih lanjut dalam anggaran dasar, anggaran rumah tangga dan keputusan rapat anggota.

d. Simpanan sukarela dan umum adalah sejumlah dana yang diserahkan oleh anggota kepada koperasi atas kehendak sendiri sebagai simpanan simpanan ini dapat diambil oleh pemilik setiap saat. karena, simpanan sukarela dikelompokan sebagai hutang jangka pendek.

Berdasarkan pengertian simpanan anggota menurut beberapa para ahli diatas, maka penulis menarik kesimpulan bahwa simpanan anggota dibedakan menjadi beberapa simpanan yaitu: simpanan pokok, simpanan wajib, simpanan sukarela.

\section{Pengertian Pinjaman Anggota}

Menurut Undang-Undang No. 17 tahun 2012 tentang perkoperasian, pinjaman didefinisikan sebagai penyediaan uang oleh koperasi kepada anggota sebagai peminjam berdasarkan perjanjian yang mewajibkan peminjam untuk melunasi dalam jangka waktu tertentu dan membayar jasa.

Menurut Ardiyos dalam (Fitrio, 2018) menyatakan bahwa pinjaman merupakan barang atau jasa yang menjadi kewajiban pihak yang satu untuk dibayarkan kepada pihak lain sesuai dengan perjanjian tertulis maupun lisan, yang dinyatakan atau diimplementasikan serta wajib dibayarkan kembali dalam jangka waktu tertentu.

Dinas Koperasi dan UKM (2019) tentang penilaian kesehatan KSP, menyatakan bahwa pinjaman yang diberikan merupakan dana yang dipinjamkan dan dana tersebut masih ada ditangan peminjam atau sisa dari pinjaman pokok tersebut yang masih belum dikembalikan oleh peminjam.

Total Pinjaman $=$ Pinjaman Pokok + Bunga

\section{Pengertian Jumlah Anggota}

Ketentuan pasal 18 ayat (1) UU No 25 tahun 1992 dinyatakan bahwa "Yang dapat menjadi anggota koperasi adalah setiap warga Negara Indonesia yang mampu melakukan tindakan hukum, atau koperasi yang memadai persyaratan seperti ditetapkan dalam anggaran dasar".

Menurut UU No 25 pasal 20 ayat (2) hak dari setiap anggota koperasi antara lain sebagai

berikut:

1. Hadir dalam rapat anggota.

2. Menyatakan pendapat dalam rapat anggota.

3. Memberikan suara di dalam rapat anggota. 
4. Memilih dan dipilih di dalam kepengurusan (sebagai pengurus atau sebagai pengawas).

5. Meminta dinyatakan diadakannya rapat anggota menurut ketentuan dalam anggaran dasar.

6. Mengemukakan pendapat atau saran kepada pengurus diluar rapat anggota, baik diminta maupun tidak .

7. Memanfaatkan koperasi dan dapat pelayanan yang sama antara sesama anggota koperasi.

8. Mendapatkan keuntungan atau sisa hasil usaha.

9. Memberikan pengembalian uang simpanan sebagai anggota.

10. Menerima bonus atau bunga atas modal saham, obligasi dan sebagainya.

11. Menerima kembali modal saham, obligasi jika anggota tersebut mengundurkan diri sebagai anggota koperasi tersebut.

12. Mengundurkan diri sebagai anggota koperas.

13. Mengawasi jalannya organisasi koperasi.

14. Mendapatkan keterangan-keterangan tentang perkembangan dari koperasi.

Dari hak yang telah ditentukan oleh UU dapat dipahami bahwa setiap anggota memiliki hak dan kewajiban yang sama. Pada koperasi tidak adanya unsur paksaan terhadap setiap anggota, dimana setiap anggota dibebaskan mengeluarkan pendapat dan memberikan masukan untuk koperasi sehingga koperasi dapat berjalan dengan baik dan semakin maju.

\section{Pengertian Sisa Hasil Usaha}

Pembahasan mengenai pengertian koperasi bila ditinjau menurut UU No.25/1992, tentang perkoperasian, Bab IX, pasal 45 adalah sebagai berikut:

a. SHU koperasi adalah pendapatan koperasi yang diperoleh dalam satu tahun buku dikurang dengan biaya, penyusutan, dan kewajiban lain termasuk pajak dalam tahun buku yang bersangkutan.

b. SHU setelah dikurangi dana cadangan, dibagikan kepada anggota sebanding jasa usaha yang dilakukan oleh masing-masing anggota dengan koperasi, serta digunakan untuk keperluan pendidikan perkoperasian dan keperluan koperasi, sesuai dengan keputusan Rapat Anggota.

c. Besarnya pemupukan modal dana cadangan ditetapkan dalam Rapat Anggota.

d. Penetapan besarnya pembagian kepada para anggota dan jenis serta jumlahnya ditetapkan oleh Rapat Anggota sesuai dengan AD/ART Koperasi.

e. Besarnya SHU yang diterima oleh setiap anggota akan berbeda, tergantung besarnya partisipasi modal dan transaksi anggota terhadap pembentukan pendapatan koperasi.

f. Semakin besar transaksi(usaha dan modal) anggota dengan koperasinya, maka semakin besar SHU yang akan diterima. 


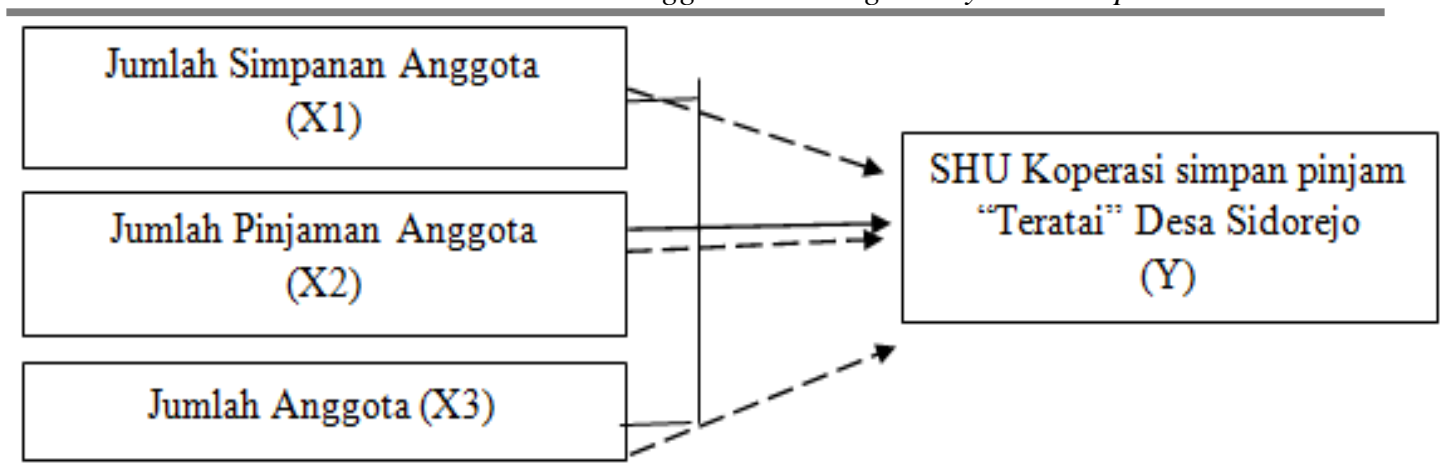

\section{Gambar 1 \\ Kerangka Konsep}

Didalam AD/ART koperasi telah ditentukan pembagian SHU sebagai berikut: Cadangan koperasi $40 \%$, jasa anggota $40 \%$, dana pengurus $5 \%$, dana karyawan $5 \%$, dana pendidikan 5\%, danasosial 5\%, dana pembangunan lingkungan $5 \%$.

Berikut Rumus Sisa hasil Usaha (SHU) :

SHU per anggota $=\frac{\text { Total Simpanan Anggota } \mathrm{x} \text { Pendapatan }}{\text { Jumlah Seluruh Simpanan Anggota }}$

\section{METODE PENELITIAN}

Dalam penelitian ini pendekatan yang digunakan oleh peneliti adalah metode kuantitatif. Dalam penelitian ini menggunakan dua veriabel yaitu variabel dependen dan variabel inependen.

Jenis data yang digunakan dalam penelitian ini adalah data sekunder meliputi data Simpanan anggota, pinjaman anggota, jumlah anggota dan sisa hasil usaha di Koperasi Wanita "Teratai" tahun 2016-2020. Sumber data yang digunakan dalam analisis ini adalah data yang diambil langsung dari kantor Balai Desa Sidorejo.

Teknik pengujian data yang digunakan meliputi uji normalitas, uji heterokedastisitas, uji multikolinearitas, dan analisis berganda. Untuk menjawab pertanyaan penelitian mengenai manakah antara ketiga variabel X1, X2, Dan X3 yang berpengaruh dominan menggunakan regresi berganda dengan pendekatan estimasi teknik data dalam penelitian ini menggunakan metode kuantitatif dengan menggunakan alat bantu SPSS (Statistic Product and Service Solution) for window.

\section{HASIL DAN PEMBAHASAN}

\section{Uji Normalitas}

Uji Normalitas dalam penelitian ini menggunakan uji non-parametrik Kolmogorov-Smirnov (K-S). Jika nilai signifikan lebih besar dari 0,05 maka nilai residual berdistribusi normal sebaliknya Jika nilai signifikan lebih kecil dari 0,05 maka nilai residual tidak berdistribusi normal. Berikut ini hasil dari uji normalitas pada residual: 
Tabel 1

Uji Normalitas

One-Sample Kolmogorov-Smirnov Test

\begin{tabular}{lll}
\hline & & Unstandardized Residual \\
\hline $\mathrm{N}$ & & 5 \\
Normal Parametersa,b & Mean &, 0000000 \\
& Std. Deviation & 39699,37420643 \\
Most Extreme Differences & Absolute &, 236 \\
& Positive &, 172 \\
& Negative &,- 236 \\
Test Statistic & &, 236 \\
Asymp. Sig. (2-tailed) & & $, 200 \mathrm{c}, \mathrm{d}$ \\
\hline
\end{tabular}

a. Test distribution is Normal.

b. Calculated from data.

c. Lilliefors Significance Correction.

$\mathrm{d}$. This is a lower bound of the true significance.

Sumber : Data Diolah, 2021

Tabel 2

Hasil Analisis Data Berganda

\begin{tabular}{|c|c|c|c|c|c|c|}
\hline & \multicolumn{3}{|c|}{ Unstandardized Coefficients } & \multirow{2}{*}{$\begin{array}{c}\text { Standardized } \\
\text { Coefficients }\end{array}$} & \multirow[t]{2}{*}{$\mathrm{t}$} & \multirow[t]{2}{*}{ Sig. } \\
\hline Model & & $\mathrm{B}$ & Std. Error & & & \\
\hline 1 & (Constant) & 19590,216 & $\begin{array}{c}8686 \\
46,82 \\
5\end{array}$ & & ,023 & ,986 \\
\hline & SIMPANAN & $6,368 \mathrm{E}-6$ &, 000 & 009 & ,341 &, 791 \\
\hline & PINJAMAN & 1,781 & 041 & ,998 & 43,225 &, 015 \\
\hline & ANGGOTA & 512,067 & $\begin{array}{c}9866, \\
187\end{array}$ & ,001 &, 052 & ,967 \\
\hline
\end{tabular}

Dependent Variable: Sisa Hasil Usaha

Sumber: Data Diolah, 2021

Berdasarkan hasil uji normalitas diperoleh hasil kolmogorov smirnov hitung sebesar 0,236 dengan probabilitas 0,200. Karena nilai probability 0,200 > 0,05 maka dapat disimpulkan distribusi variabel normal.

\section{Teknik Analisis Data Regresi Berganda}

Analisis Regresi Linier berganda untuk menghitung besarnya pengaruh antara variabel independen yaitu simpanan (X1), pinjaman anggota (X2), dan Jumlah Anggota (X3) terhadap variabel dependen yaitu sisa hasil usaha (Y).

Berdasarkan tabel diatas, pada kolom B tercantum nilai konstanta dan nilai-nilai koefisien regresi linier berganda untuk masing-masing variabel bebas dan terikat. Berdasarkan hasil uji diperoleh persamaan regresi linier berganda sebagai berikut :

$\mathrm{Y}=19590,216+6,368 \mathrm{X} 1+1,781 \mathrm{X} 2+512,067 \mathrm{X} 3+\mathrm{e}$

Berdasarkan rumus regresi linier berganda diatas dapat dinyatakan nilai koefisiennya sebagai berikut: 
a. Nilai konstanta sebesar 19590,216

Dalam hal ini menunjukan bahwa apabila seluruh variabel bebas simpanan (X1), pinjaman anggota (X2), dan Jumlah Anggota (X3) dianggap konstan pada angka 1 maka sisa hasil usaha akan bernilai positif.

b. Nilai koefisien $\beta$ variabel simpanan (b1) sebesar 6,368

Tanda positif menunjukkan hubungan bahwa setiap kenaikan variabel simpanan sebesar 1\%, maka sisa hasil usaha akan meningkat sebesar 6,368 pada saat variabel lain tidak mengalami perubahan (tetap). Hal ini menegaskan apabila Koperasi Wanita "Teratai" meningkatkan simpanannya maka SHU mengalami Peningkatan.

c. Nilai koefisien $\beta$ variabel pinjaman anggota (b2) sebesar 1,781

Tanda positif menunjukkan bahwa setiap kenaikan variabel pinjaman anggota sebesar $1 \%$, maka sisa hasil usaha akan meningkat sebesar 1,781 pada saat variabel lain tidak mengalami perubahan (tetap). Hal ini menegaskan apabila Koperasi Wanita "Teratai" meningkatkan pinjaman anggotanya maka SHU mengalami Peningkatan

d. Nilai koefisien $\beta$ variabel jumlah anggota (b3) sebesar 512,067

Tanda positif menunjukkan bahwa setiap kenaikan variabel jumlah anggota sebesar 1\%, maka sisa hasil usaha akan meningkat sebesar 512,067 pada saat variabel lain tidak mengalami perubahan (tetap)

\section{Hasil Uji Hipotesis Uji F (Simultan)}

Uji $F$ digunakan untuk menguji pengaruh variabel bebas terhadap variabel terikat secara bersama- sama dengan taraf signifikan yang digunakan adalah 0,05 dengan membandingkan nilai Fhitung dengan Ftabel. Kriteria hipotesis diterima jika Fhitung $>$ Ftabel dan nilai sig $<\alpha$.

Berdasarkan hasil pengujian hipotesis dengan menggunakan uji $\mathrm{F}$, diperoleh Fhitung sebesar 693,413 sedangkan nilai Ftabel pada taraf identifikasi a $=0,05$ dan derajat kebebasan $(\mathrm{df}=3 ; 1)$ adalah sebesar 216 .

Tabel 3

Hasil Analisis Uji F ANOVA ${ }^{\text {a }}$

\begin{tabular}{|c|c|c|c|c|c|c|}
\hline & Model & $\begin{array}{l}\text { Sum of } \\
\text { Squares }\end{array}$ & df & $\begin{array}{l}\text { Mean } \\
\text { Square }\end{array}$ & $\mathrm{F}$ & Sig. \\
\hline \multirow[t]{4}{*}{1} & Regression & 131141547 & 3 & 4371384925 & $693,41,3$ &, $028 b$ \\
\hline & & 77471,672 & & 823,891 & & \\
\hline & Residual & $\begin{array}{c}630416124 \\
9.530\end{array}$ & 1 & $\begin{array}{c}6304161249 \\
.530\end{array}$ & & \\
\hline & Total & $\begin{array}{l}131204589 \\
38721,201\end{array}$ & 4 & & & \\
\hline
\end{tabular}

a. Dependent Variable: SHU

b. Predictors: (Constant), ANGGOTA, PINJAMAN, SIMPANAN

Sumber : Data Diolah, 2021 
Tabel 4

Uji t

\begin{tabular}{lllll}
\hline Variabel & T hitung & Sig. & T tabel \\
\hline 1 & (Constant) &, 023 &, 986 & \\
& SIMPANAN &, 341 &, 791 & 12.706 \\
& PINJAMAN & 43,225 &, 015 & 12.706 \\
& ANGGOTA &, 052 &, 967 & 12.706 \\
\hline
\end{tabular}

Sumber: Data Diolah, 2021

Dari hasil analisis tersebut terlihat bahwa nilai $F_{\text {hitung }}$ lebih besar dari nilai $F_{\text {tabel }}(693,413<216)$ dan nilai signifikansi sebesar 0,028 lebih kecil dari 0,05 maka dapat disimpulkan bahwa hipotesis diterima, yaitu ada pengaruh simpanan dan pinjaman anggota secara bersama-sama terhadap sisa hasil usaha pada Koperasi "Wanita".

\section{Uji t}

Uji t digunakan untuk menguji pengaruh masing-masing variabel bebas terhadap variabel terikat dengan taraf signifikan yang digunakan adalah 0,05 dengan membandingkan nilai thitung dengan ttabel. Kriteria hipotesis diterima jika thitung $>$ ttabel dan nilai sig $<\alpha$.

Berdasarkan hasil pengujian hipotesis dengan menggunakan uji $t$, nilai ttabel pada taraf signifikan $\mathrm{a}=0,05(\mathrm{a} / 2=0,025)$ dan derajat kebebasan $(\mathrm{df})=1$ adalah 12.706 Diperoleh nilai thiting variabel simpanan sebesar 0,341 lebih kecil dari ttabel $(0,341<12.706)$ dan nilai signifikan sebesar 0,791 lebih besar dari tingkat kekelituan $a=0,05$ maka dapat diambil kesimpulan untuk menolak hipotesis artinya simpanan tidak berpengaruh terhadap sisa hasil usaha.

Diperoleh nilai thitung variabel bebas pinjaman anggota sebesar 43,225 dari hasil analisis tersebut dilihat bahwa nilai thitung lebih besar dari ttabel $(43,225>12.706)$ dan nilai signifikansi sebesar 0,015 lebih kecil dari tingkat kekeliruan $\alpha=0,05$ maka dapat diambil kesimpulan untuk menerima hipotesis. Artinya pinjaman anggota berpengaruh terhadap sisa hasil usaha pada Koperasi Wanita "Teratai".

Diperoleh nilai thiting variabel jumlah anggota sebesar 0,052 lebih kecil dari ttabel $(0,052<12.706)$ dan nilai signifikan sebesar 0,967 lebih besar dari tingkat kekeliruan $\mathrm{a}=0,05$ maka dapat diambil kesimpulan untuk menolak hipotesis artinya jumlah anggota tidak berpengaruh terhadap sisa hasil usaha.

\section{SIMPULAN}

Penelitian ini bertujuan untuk mengetahui pengaruh simpanan dan pinjaman anggota terhadap sisa hasil usaha pada Koperasi Wanita "Teratai" Periode 20162020. Berdasarkan hasil penelitian dan pembahasan, maka dapat diambil kesimpulan sebagai berikut: 1. Temuan hasil peneliti bahwa Simpanan tidak berpengaruh secara signifikan terhadap sisa hasil usaha pada Koperasi Wanita "Teratai". 2. Temuan hasil peneliti bahwa Pinjaman anggota berpengaruh secara signifikan terhadap sisa hasil usaha Koperasi Wanita "Teratai" . 3. Temuan hasil peneliti bahwa Jumlah anggota tidak berpengaruh secara signifikan terhadap sisa hasil usaha pada Koperasi Wanita "Teratai". 4. Temuan hasil peneliti terdahap Simpanan, pinjaman dan jumlah anggota berpengaruh terhadap sisa hasil usaha 
pada Koperasi Wanita "Teratai" ditunjukkan dengan nilai signifikansi sebesar 0,028 lebih kecil dari 0,05 maka dapat disimpulkan bahwa hipotesis diterima.

\section{DAFTAR PUSTAKA}

Anindyatama, M. D., Kusmayadi, dan Anugrahwati, L. M. 2019. Analisis pengaruh jumlah anggota, simpanan anggota, dan piutang anggota terhadap sisa hasil usaha pada primkopkar manunggal damatextimatex salatiga. Skripsi, Salatiga. Diakses tanggal 17 mei 2021, pukul 21.00.

Aziz, 2020. Dampak Psikologis Pandemi Covid-19 pada Tenaga Kesehatan: A Studi Cross- Sectional di Kota Pontianak. Jurnal kesehatan masyarakat indonesia. Diakses tanggal 1 Mei 2021, pukul 22.00

Davies, R. (2015). Industry 4.0 Digitalisation for productivity and growth. http://www.europarl.europa.eu/RegData/etudes/BRIE/2015/568337/EPRS_ BRI(2015)568337_EN.pdf, Diunduh pada 11 Maret 2017

Fitrio,T. 2018. Pengaruh Simpanan dan Pinjaman yang disalurkan terhadap Pendapatan Pada Simpan Pinjam Perempuan Unit Pengelola Kegiatan (SppUpk) Lufkin Kecamatan Lirik Kabupaten Indragiri Hulu. Jurnal Manajemen Dan Bisnis, 7(02): 11-26. Diakses tanggal 20 April 2021, pukul 14.00

Ghozali, Imam. 2018. Aplikasi Analisis Multivariete Dengan Program IBM SPSS 23 (Edisi 8). Cetakan ke VIII. Semarang : Badan Penerbit Universitas Diponegoro. Halaman belum hal 56 hal 60 p dihilangi

Hasibuan, D. M., dan Purba, E. 2019. Pengaruh Simpanan Anggota dan Pinjaman Anggota Terhadap Sisa Hasil Usaha (SHU) Di CU. Maju bersama kabupaten simalungun. Jurnal Ekonomi Pembangunan, 1(1): 9-15. Diakses tanggal 1 Mei 2021, pukul 23.00

Iqbal, M., dan Widiya, L. 2018. Pengaruh Simpanan Pokok dan Pinjaman Anggota Terhadap Sisa Hasil Usaha pada Koperasi Kredit Buanan Endah Tahun Periode 2010-2016. Jurnal Ilmiah Akuntansi, 9(3): 65-86. Diakses tanggal 26 Juni 2021, pukul 16.00

Kefi, D. Y. 2019. Pengaruh Simpanan Anggota Dan Pinjaman Anggota Terhadap Perolehan Sisa Hasil Usaha (Shu) Kopdit Timau Kupang. Jurnal Politeknik Negeri Kupang, 3(2): 20-29. Diakses tanggal 4 April 2021, pukul 19.00

Keputusan Menteri Koperasi dan Usaha Kecil dan Menengah Republik Indonesia No.20/PEM/M.KUKM/XI/2008 ayat (7) tentang pinjaman anggota.

Keputusan Menteri Negara Koperasi dan Usaha Kecil dan Menengah Republik Indonesia No.96/KKEP/M.KUKM/IX/2004 pasal (1) tentang koperasi simpan pinjam. 
Keputusan Menteri Negara Koperasi dan Usaha Kecil dan Menengah Republik Indonesia No.96/KKEP/M.KUKM/IX/2004 pasal (16) tentang bunga simpanan.

Keputusan Menteri Negara Koperasi dan Usaha Kecil dan Menengah Republik Indonesia No.96/KKEP/M.KUKM/IX/2004 pasal (22) Tentang Bunga Pinjaman.

Kristanti, M. 2018. Pengaruh Perputaran Kas, Jumlah Simpanan, Jumlah Pinjaman Terhadap Sisa Hasil Usaha Koperasi Wanita Yang Bernaung di bawah Dinas Tenaga Kerja Koperasi dan Usaha Mikro Kabupaten Nganjuk. Skripsi Universitas Nusantara PGRI Kediri, 1-13. Diakses tanggal 24 April 2021, pukul 13.00

Maharani. Atika Agustavia. 2018. Analisis Tingkat Kesehatan Koperasi Simpan Pinjam di Kecamatan Bantul Kabupaten Bantul Tahun 2017. Skripsi. FEB. Diakses tanggal 18 Februari 2021, pukul 12.00 hal 27

Mbulu, Y., Kellen, P. B., Ndoen, L. M., dan Marselinus, B. 2019. Pengaruh Jumlah Simpanan dan Jumlah Pinjaman Anggota Terhadap Sisa Hasil Usaha Pada Koperasi Kredit Handayani Bajawa. Jurnal Akuntansi: Transparansi Dan Akuntabilitas, 7(2): 165-172. Diakses tanggal 6 Mei 2021, pukul 22.00

Muljono, Djoko. 2012. Buku Pintar Strategi Bisnis Koperasi Simpan Pinjam. Yogyakarta : Andi.

Naeshela, Feny. 2016. Perancangan Aplikasi Koperasi Simpan Pinjam Berbasis Web (Studi Kasus Koperasi Mitra Setia) Diambil dari: http://eprints.ummi.ac.id/60/3/Perancangan\%20Aplikasi\%20Koperasi\% 20Simpan\%20Pinjam\%20Berbasis\%20Web\%20\%28Studi\%20Kasus\%2 OKoperasi\%20Mitra\%20Setia\%29.pdf, di akses pada tanggal 21 Februari 2021.

Ninik, Widiyanti dan Sunindhia. 2016. Koperasi dan Perekonomian Indonesia. Jakarta: Rineka Cipta.

Novita,Yus. 2017. Analisis Faktor - Faktor Penyebab Penurunan Sisa Hasil Usaha Pada Koperasi BMT Mu'awanah Kota Palembang. Skripsi. Universitas Muhammadiyah Palembang. Diakses tanggal 6 Mei 2021, pukul 21.00

PP (Peraturan Pemerintah) No. 9 Tahun 1995 tentang pelaksanaan kegiatan usaha simpan pinjam.

Rahmawati. (2016). Seminar Hasil TIMMS 2015. Diakses pada 24 Februari 2017 dari http://puspendik.kemdikbud.go.id/seminar/upload/RahmawatiSeminarHasil- TIMSS-2015.pdf 
Raidayani, Muhammad dan Faisal. 2017. Faktor - Faktor Yang Mempengaruhi Sisa Hasil Usaha (SHU) pada Koperasi di Kabupaten Aceh Barat. Jurnal Perspektif Ekonomi Darussalam Vol. 2. No. 2: 167-184. Diakses tanggal 12 Mei 2021, pukul 15.00

Rosa, Dwi. 2018. Pengaruh Jumlah Anggota dan Jumlah Simpanan Terhadap Sisa Hasil Usaha pada PKP-RI Kabupaten Langkat. Skripsi fakultas Ekonomi dan Bisnis universitas Medan Area. Diakses tanggal 15 Meret 2021, pukul 16.00

Rudianto. 2017. Akuntansi Koperasi Edisi Kedua. Jakarta: Erlangga

Rupitasari, R. Medinal, dan panjaitan, F. 2017. Analisis Pengaruh Jumlah Simpanan Anggota, Jumlah Pinjaman Anggota Dan Modal Kerja Terhadap Sisa Hasil Usaha. Jurnal Ilmiah Bisnis dan Keuangan. Diakses tanggal 7 Februari 2021, pukul 14.00

Saputra, R. M. I. 2017. Pengaruh Simpanan Dan Pinjaman Anggota Terhadap Sisa Hasil Usaha (SHU) Pada Koperasi Pegawai Republik Indonesia (KpRi) Smp Negeri Kabupaten Indragiri Hulu. Jurnal Eko Dan Bisnis (Riau Economics and Business Reviewe), 8(4): 82-89. Diakses tanggal 24 April 2021, pukul 20.00

Sari, R. 2019. Analisis Pengaruh Tingkat Simpanan dan Pinjaman Anggota Terhadap Sisa Hasil Usaha (SHU) Kopsyah BMT Al-Amin Pekanbaru. Skripsi Fakultas Ekonomi Universitas Pasir Pengaraian.

Silalahi, Ulber. 2015. Metode Penelitian Sosial Kuantitatif. Bandung: PT. Refika Aditama.

Sugiyono. 2017. Metode Penelitian Kuantitatif, Kualitatif, dan R\&D. Bandung: Alfabeta

Sugiyono. 2018. Metode Penelitian Kuantitatif, Kualitatif, dan $R \& D$. Bandung: Alfabeta

Sugiyono. 2019. Metode Penelitian Kuantitatif, Kualitatif, dan $R \& D$. Bandung: Alfabeta Tiktik S, Partomo. Ekonomi Industri. Jakarta: Penerbit Inti Prima, 2018.

Undang-Undang Negara Republik Indonesia No 17 Tahun 2012 Pasal 4 Tentang Perkoperasian.

Undang-Undang Negara Republik Indonesia No 25 Tahun 1992 Pasal 1 Ayat 1 tentang perekonomian.

Undang-Undang Negara Republik Indonesia No 25 Tahun 1992 Pasal 3 tentang tujuan koperasi. 
Undang-Undang Negara Republik Indonesia No 25 Tahun 1992 Pasal 33 Ayat 1 tentang simpanan pokok.

Undang-Undang Negara Republik Indonesia No 25 Tahun 1992 Pasal 33 Ayat 2 tentang simpanan wajib.

Undang-Undang Negara Republik Indonesia No 25 Tahun 2012 Pasal 20 ayat 2 Tentang hak setiap anggota koperasi.

Wijayanti, N. 2017. Faktor-Faktor Yang Mempengaruhi Sisa Hasil Usaha Pada Koperasi Syariah di Kabupaten Karanganyar. Skripsi Fakultas Ekonomi Dan Bisnis Islam Institut Agama Islam Negeri Surakarta. Diakses tanggal 26 April 2021, 20.00

Winarno, Sigit dan Sujana Ismaya. Kamus Besar Ekonomi, Bandung : Pustaka Grafika, 2016 